\title{
A tribute to Natsurang Homchantara (1957-2006)
}

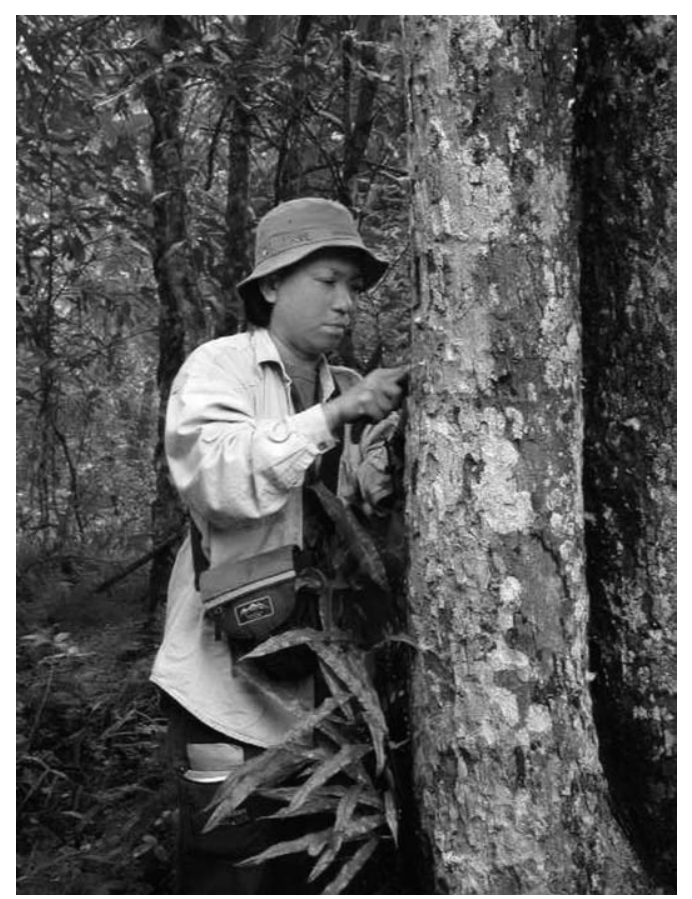

Assistant Professor Dr Natsurang Homchantara was Thailand's first trained lichen taxonomist. Not only did she lay down a solid foundation for the systematic study of lichens in this country; she was also widely recognized as a very kind individual, ready to lend a helping hand to all. Besides being a good scientist, she followed the philosophy of Buddhism, practiced meditation, and was supportive of others. She was a truly outstanding person.

Natsurang Homchantara was born in Bangkok on 27 May 1957 to Sueb and Lamyai Homchantara. She was often called by her nickname Oy, which in Thai means sugar cane. The fourth of five children, she enjoyed a warm and pleasant relationship with members of her family, which was a source of great joy to her. Having received a B.Sc. in Botany from Kasetsart University in 1979, Natsurang went on to work as a scientist at the Department of Pharmacognosy in the Faculty of Pharmaceutical Science at Chulalongkorn University. It was at this institute that Natsurang developed her skills pertaining to natural products and herbal medicines produced from local plants. Later, she enrolled in the graduate programme at Chulalongkorn University and in 1985 received an M. Sc. in Pharmacy (Pharmacognosy). In 1991, she transferred to Ramkhamhaeng University (RU) in Bangkok to assume the position of an instructor at the Department of Biology in the Faculty of Science. It was during her years at this institute that I first got to know her, and was impressed with the way she worked.

In 1989, the University supported a lichen project regarding air pollution in Bangkok, but unfortunately I ran into problems regarding the identification of lichens in Thailand. However, Professor John Elix kindly lent us a hand to overcome these problems. In December 1991, Natsurang attended a lichen workshop at Changmai University in northern Thailand organized by Pat Wolseley and Begoña Aguirre-Hudson. In 1997 she made a considerable contribution towards organizing a lichen workshop held at RU and Khao Yai national park and supported by BIOTEC Thailand. Brian Coppins and Pat McCarthy were guest instructors, with co-operation from Pat Wolseley. A Lichen Research Unit was then established at RU, with Natsurang being the principal researcher in taxonomy. Subsequently, the Thai government, through RU, awarded a scholarship to Natsurang to 
pursue a Ph. D. and in 1997 she was admitted as a Ph.D. candidate at Liverpool John Moores University under the supervision of Professor Anthony Whalley and Dr Brian Coppins. She worked with Brian Coppins at the Royal Botanic Garden in Edinburgh, and received her Ph.D. in 1999. In her thesis Natsurang, together with Brian Coppins, described thirty new species of Thelotremataceae.

On returning home, Natsurang continued her work, strengthening the study of the taxonomy of tropical lichens at RU. She enjoyed working as a lichenologist, in addition to which she devoted her spare time during weekends to charity work and meditation at her favourite temple in Uthaitani, north of Bangkok. In 2004, however, she began to suffer from health problems. Nevertheless, she faced the situation in full spirits, being at heart a cheerful person, and was always keen to work. Finally, on 11 August 2006, at the relatively young age of forty nine, Natsurang passed away, after spending almost two years battling with cancer. It is a great loss to the world of academia, and to the study of lichens in Thailand. Nevertheless, her work on the taxonomy of lichens, especially the family Thelotremataceae, as well as on herbal medicine, continues to be used by students and researchers alike. Two newly described lichens collected in Thailand were named to honour her; Cladonia homchantarae Ahti \& Parnmen and Chroodiscus homchantarae Papong \& Lücking.

\section{Kansri Boonpragob}

K. Boonpragob: Department of Biology, Faculty of Science, Ramhamhaeng University, Bangkok 10240, Thailand. Email: kansri@ru.ac.th 